\title{
Coping Action Oriented to Early Stimulation of Children with Congenital Zika Virus Infection in Rio de Janeiro State
}

\author{
Miriam Ribeiro Calheiros de Sá1 (1), Paula de Almeida Thomazinho' ${ }^{1}$ (D), \\ Carla Trevisan Martins Ribeiro ${ }^{1}$ (), Natália Anachoreta Molleri ${ }^{1}$ (D), \\ Maria Luciana de Siqueira Mayirink ${ }^{1}$ (D), Polyanna Nascimento Mendes ${ }^{1}$ (D), \\ Tatiana Hamanaka1 ${ }^{10}$, Lívia Peluso Rossi ${ }^{1}$ (), Thaís Severino da Silva², Dayanne Lucena², \\ Maria Elisabeth Lopes Moreira1 (i)
}

\begin{abstract}
${ }^{1}$ National Institute of Women, Children and Adolescents Health Fernandes Figueira-Fiocruz, Rio de Janeiro, Brazil
${ }^{2}$ Rio de Janeiro State Health Department, The Superintendent of Primary Health Attention, Rio de Janeiro, Brazil

Email: miriam.sa@iff.fiocruz.br, paula.thomazinho@iff.fiocruz.br, natalia.molleri@iff.fiocruz.br, maria.mayrink@iff.fiocruz.br, polyanna.mendes@iff.fiocruz.br, tatiana.hamanaka@iff.fiocruz.br, livia.rossi@iff.fiocruz.br, thais.severino79@gmail.com, dayanne.lucena@saude.rj.gov.br, bebethiff@gmail.com
\end{abstract}

How to cite this paper: de Sá, M.R.C., de Almeida Thomazinho, P., Ribeiro, C.T.M., Molleri, N.A., de Siqueira Mayirink, M.L., Mendes, P.N., Hamanaka, T., Rossi, L.P., da Silva, T.S., Lucena, D. and Moreira, M.E.L. (2019) Coping Action Oriented to Early Stimulation of Children with Congenital Zika Virus Infection in Rio de Janeiro State. Health, 11, 1152-1161. https://doi.org/10.4236/health.2019.119089

Received: August 14, 2019

Accepted: September 23, 2019

Published: September 26, 2019

Copyright $\odot 2019$ by author(s) and Scientific Research Publishing Inc. This work is licensed under the Creative Commons Attribution International License (CC BY 4.0).

http://creativecommons.org/licenses/by/4.0/

\section{c) (i) Open Access}

\begin{abstract}
New health care demands directed at children with chronic conditions have been demanded mainly after the Zika virus epidemic. Given this, the Brazilian states have produced plans to cope with this congenital infection. In the state of Rio de Janeiro, the elaborated plan had as one of its actions a training proposal for physiotherapists, speech therapists and occupational therapists, focusing on early stimulation and focused on the health care network, especially primary care and specialized rehabilitation centers. Thus the purpose of this article is to describe the impact of a response strategy to Zika virus congenital infection, based on the multi-professional training proposal in earlier stimulation in the public health attention network of Rio de Janeiro State. Descriptive study, observational from the earlier stimulation training course to the public health attention network of Rio de Janeiro State as a coping action to the health care of children with Zika virus congenital infection. At the time of writing, partial results are available after 11 classes were performed. Based on the analysis of the evaluation form of the 11 courses taught by professionals of a referral hospital in Rio de Janeiro and student form, using the Excel program, 299 health network professionals were qualified, from 56 different municipalities of RJ, mostly females $(\mathrm{n}=259$; 86.82\%). 175 physiotherapists (59\%), 88 speech therapists (29\%), 32 occupational therapists (11\%) and 4 academics or other professional backgrounds (1\%). The articulation between the different levels of public assistance, specifically: primary, sec-
\end{abstract}


ondary and tertiary, in this context assumes a fundamental action for good practices being undertaken considering the population's health demands. Especially in relation to childhood chronic disease conditions, this action permited the building of lines of care that meet the population's health demands so that in any of a child's entry points on the assistance network, either prevention or treatment of the aggravated cases, there is integration of the actions and a better resolving response. It could be also identified that the strategy covered both the primary health attention team and the specialized rehabilitation team equally, composing one more important dialogue point to build an articulated and integrated assistance network.

\section{Keywords}

Delivery of Health Care, Zika Virus, Chronic Disease, Child, Intersectoral Collaboration

\section{Introduction}

New care demands directed at child health are required considering the continuous increase in prevalence of chronic aggravated health conditions and/or chronic disease throughout the world, including developing countries [1]. Among these conditions, the congenital alterations related to the Zika virus outbreak, identified in Brazil in 2015, stands out. Given the identified neurological deficit conditions, exposure to Zika virus impacts in a greater or lesser degree on infant growth and development with life-long repercussions [2].

The congenital syndrome associated with the Zika virus (CZS) is characterized by presenting among its clinical manifestations: those stemming from central nervous system malformation such as microcephaly, spasticity, irritability, seizure episodes with control difficulties, sensory alterations (hearing and visual), on the ocular structures and orthopedics (arthrogryposis, congenital club foot, hip dislocation), dysphagia and neurogenic bladder. Thereby neurosensory-motor development is significantly compromised and early specialized and continuous care, performed by a multitask professional team is essential [3] [4] [5] [6] [7].

In Brazil in November 2015, the Ministry of Health declared a Public Health Emergency related to Zika and microcephaly [8] and immediately afterwards in February 2016, the World Health Organization (WHO) declared a Public Health Emergency of International Concern [9]. According to the Epidemiological Report from the Ministry of Health of April 2019, an actual incidence of Zikainfeccion is of 1.1 cases per 1000 inhabitants. The epidemic had an asymmetrical distribution throughout Brazil and the most affected regions were the Northeast, Southeast and Central [8]. From the suspected cases being investigated for CZS and STORCH, from 2015 to 2019, 85\% of cases were concentrated in 11 States: Bahia; Tocantins; São Paulo; Paraíba; Rio de Janeiro; Minas Gerais; Pernambuco; 
Espírito Santo; Rio Grande do Norte; Pará and Mato Grosso [9].

From November 2015 to December 2018, were 17,041 suspect cases of growth and development disease probably related to Zikavírus infection or other infective disease notified around the country, of which 2133 (12.5\%) were excluded because they didn't meet the current case definitions. 3332 (19.6\%) were confirmed. $643(3.8 \%)$ cases were classified as likely attributable to congenital infection during pregnancy and another 486 (2.9\%) considered inconclusive, with a total of 4461 children with a potential risk of alterations in their early years or with later onset [10]. 2.612 (15.3\%) were still under investigation up to December 2018.In Rio de Janeiro State (RJ), 1180 cases of neurodevelopmental disease were notified up to the period described [10].

However, despite a large number of confirmed cases of infants and children exposed to the Zika virus throughout the country, and recognizing the repercussion of this infection in childhood development, only 1,000 (34.9\%) received specialized early stimulation treatment [10].

Considering the magnitude of cases of children with chronic aggravations in Rio de Janeiro, it was necessary to elaborate a coping plan to combat the Zika virus infection and other infectious contagious diseases in the State, composed of 9 axes (Axis I-Epidemiologic Surveillance, Axis II-Promotion and Prevention, Axis III Basic Attention, Axis IV-Specialized Attention, Axis V-Clinical Attention, Axis VI-Rehabilitation, Axis VII-Permanent Education, Axis VIIIIntersectoriality and Axis IX-Management) with the attendance of health professionals, education, State management welfare, research institutions, professional councils and reference services including the reference hospital that participated in this study [10].

Through the Rio de Janeiro State Health Department (SES/RJ), the Superintendent of Primary Health Attention and the reference hospital $(\mathrm{RH})$, a training proposal was developed that focused on earlier stimulation, aimed at the child health attention network of Rio de Janeiro State as a part of the "Implementation Plan for the Strengthening Strategy for Treatment of children suspected or confirmed with the Congenital Zika Syndrome (CZS) and others syndromes caused by syphilis, toxoplasmosis, rubella, cytomegalovirus and herpes virus (STORCH)", which is the subject of this work. The aim of this proposal is to give support and enable healthcare professionals to assist children with Zika virus congenital infections, particularly those who assist with primary health attention and specialized rehabilitation centers [11]. Thus the purpose of this article is to describe the impact of a response strategy to Zika virus congenital infection, based on the multi-professional training proposal in earlier stimulation in the public health attention network of Rio de Janeiro State.

\section{Methodology}

Descriptive study, observational from the earlier stimulation training course to the public health attention network of Rio de Janeiro State as a coping action to 
the health care of children with Zika virus congenital infection, based on course students' records, attendees' registration forms, assessment sheets from each group, and the "Implementation Plan for the Strengthening Strategy for Treatment of children suspected or confirmed with the Congenital Zika Syndrome (CZS) and others syndromes caused by syphilis, toxoplasmosis, rubella, cytomegalovirus and herpes virus (STORCH)".

The study began with the identification of the demands and needs of the assistance network in Rio de Janeiro, listed by an inter-institutional and intersectorial working group, elaborated through a SWOT (strengths, weakness, opportunities and threats) analysis; and followed the stage of building on the earlier stimulation training course. An initial meeting took place with a specialized team composed of physiotherapists, speech therapists, occupational therapists, and care specialists, where a brainstorming session was conducted with the aim of pointing out all the strengths, weakness, opportunities and threats. The list of items produced in the SWOT was refined using following parameters: the power of a factor indicated, and the probability of its occurrence. Finally, a strategy was mapped for each final list item, in order to explore the advantages and opportunities and address weakness and threats.

It was estimated 15 classes would be necessary considering the number of professionals bound to the Hub of Family Health Attention (hereby NASF) and the Specialized Rehabilitation Centre (hereby CER), established in cities of the 9 health areas of Rio de Janeiro State (Metropolitan I and II, South Center, Northwest, North Fluminense, Coastal Lowlands, Green Coast, Serrana e Middle Paraíba), considering the maximum limit of 35 professionals per class. The plan was approved by the Bipartite Interagency Commission in a regular meeting and the deliberation published in CIB-RJ $\mathrm{n}^{\circ} 5373$ on 14 June 2018, containing the agreement of places distributed per area and cities to be approved by the Standing Committee of Teaching and Service Integration of Rio de Janeiro State.

The theoretical and practical methodology was used in planning the educational actions conducted by the multi-professional team tutors, composed by physiotherapists, speech therapists, occupational therapists, and care specialists in supporting children with complex chronic conditions and CZS. The tutor team was in loco conducting courses throughout each area for 2 consecutive days, with a total workload of 20 hours per class. This work included expositive conceptual presentations and simulated actions, clinical cases presentations, debating the treatment plan and clarifying attendee's doubts about the common theme to clinical practice.

The attendee's registration forms were analyzed to capture the variables: professional category, workplace considering the care complexity level (basic attention or specialized rehabilitation service), city of work and administrative area from Rio de Janeiro.

At the end of each course, a questionnaire developed by the tutor team was given to attendees with open and closed items, with the aim to evaluate the 
taught content, with regard to the suitability, applicability, didactic content, balance among the theoretical and practical program, objectivity, workload and new knowledge acquisition; as well as the attendee performance regarding comprehension, intergroup relationship, personal involvement on the proposed activities, relationship with the tutors and the individual capacity to further disseminate material. Based on this tool it was possible to make necessary adjustments to the course during the delivery period, in the interval between each teaching event.

The study was approved by National Institute of Women, Children and Adolescents Health Fernandes Figueira Ethics Committee under 2.065.943 registration number, approved July 16, 2017, as part of the research named "Vertical exposure to Zika virus and its consequences for child neurodevelopment".

\section{Results}

At the time of writing, partial results are available after 11 classes were performed in the following areas: Metropolitan I and II (5), South Center (1), Northwest (1), North Fluminense (1), Green Coast (1) and Coastal Lowlands (1). 299 health network professionals were qualified, from 56 different municipalities of RJ, mostly females $(\mathrm{n}=259 ; 86.82 \%) .175$ physiotherapists $(59 \%), 88$ speech therapists $(29 \%)$, 32 occupational therapists (11\%) and 4 academics or other professional backgrounds (1\%). Table 1 presents demographic information and the distribution of trained professionals per municipality/administrative Region of RJ, according to total trained professionals and professional category.

The city with the highest absolute number of participants was Rio de Janeiro $(n=45)$, the region being circumscribed by the districts of Ramos, Penha, VigárioGeral, Ilha do Governador, Complexo do Alemão e Complexo da Maré

Table 1. Demographic information and distribution of trained professionals per RJ Administrative Regions.

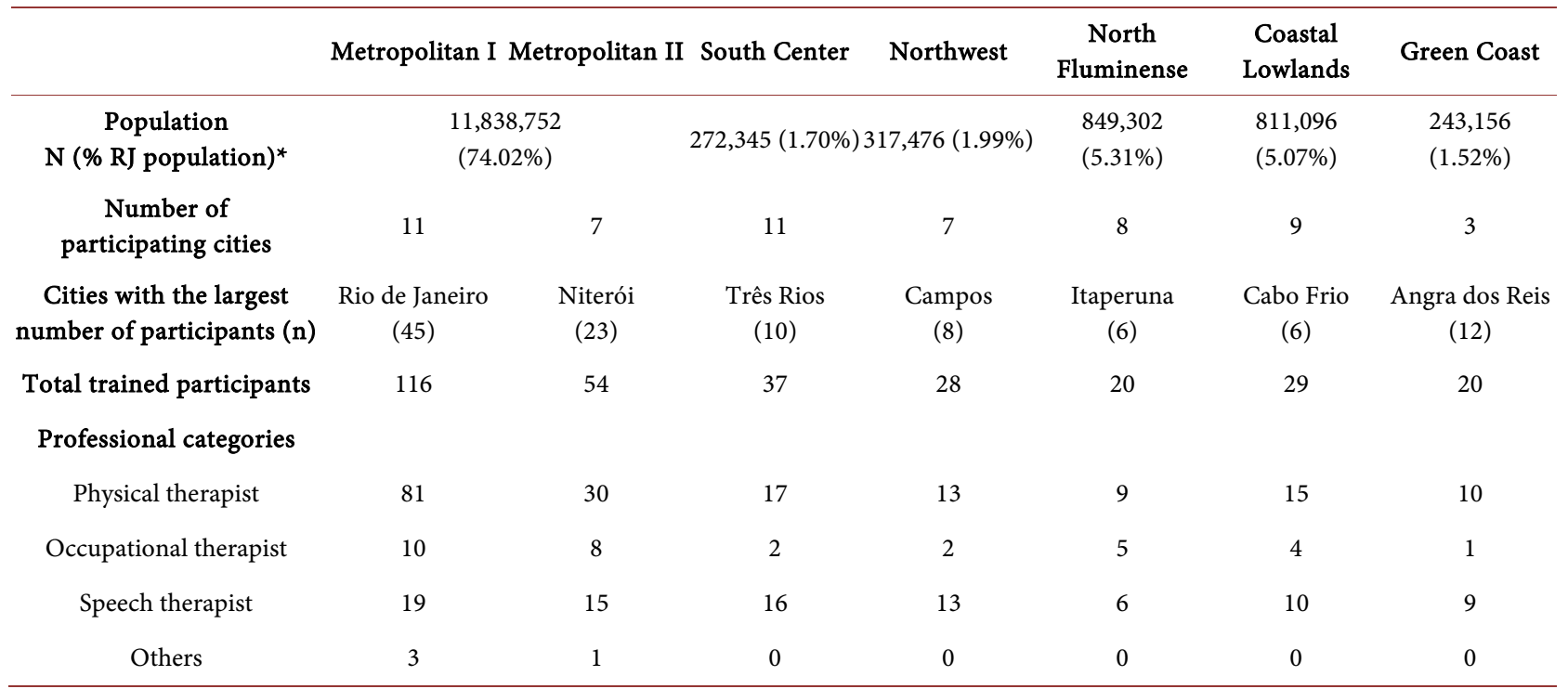

*Font: CENSO DEMOGRÁFICO 2010. Características da população e dos domicílios: resultados do universo. Rio de Janeiro: IBGE, 2011. 
(AP 3.1) with a greater number of trained professionals $(n=8)$ among those who participated with representatives. The average of participants per region was 4.5.

In regard to the workplace, among attendees who responded to the registration items, from the specialized services comprised $53.82 \%$ of the total $(n=155)$ and those attached to basic attention strategies were $43.18 \%(n=133)$.

The training course evaluation, considering the attendee's expectation, was rated as positive by $89.90 \%$ of professionals. All evaluated items had an excellence rating above $70 \%$, except the course load that had $57.65 \%$ approval among the attendees, where they registered the desire for a program extension, including the possibility of an advanced module.

A communication channel to continue the discussion was provided by a virtual knowledge portal, where professionals can send doubts derived from their assistance practice related to the topic, and these doubts are addressed through expositive activities presented by the reference hospital specialists.

\section{Discussion}

The establishment of the Unified Health System (SUS) in 1988 sought to reduce the iniquity in health access, promote equity and an evolution on different levels of health attention in the country, as demonstrated, among other aspects, by the increasing number of specialized reference centers, as well as the development of a health attention network, the care deconcentrating from different bodies, with a focus on the Family Health Program, there are in the literature evidences of improvement in care for the child population, with mortality and morbidity reduction across different age ranges [12].

The articulation between the different levels of public assistance, specifically: primary, secondary and tertiary, in this context assumes a fundamental action for good practices being undertaken considering the population's health demands. Especially in relation to childhood chronic disease conditions, this action permits the building of lines of care that meet the population's health demands so that in any of a child's entry points on the assistance network, either prevention or treatment of the aggravated cases, there is integration of the actions and a better resolving response [11].

This articulation is in accord with the Sustainable Development Goals (SDG), which as part of Agenda 2030 [13] are a global call to action for eradicating poverty, protect the planet and assure that all people live in peace and prosperity. The SDG intend to "not leave anyone behind" and they make a commitment to reach the most marginalized groups in the world. Similarly, this program is aligned to the strategic axis that forms the National Policy of Integral Attention for Child Health [14] particularly considering the axes: III-promotion and monitoring of growth and integral development; IV-comprehensive care for children with prevalent illnesses in childhood and with chronic diseases; $\mathrm{VI}-$ attention to the health of children living with disabilities or in specific situ- 
ations of vulnerability.

Thereby, there is a premise that strategies for integration between levels of assistance and permanent training of health teams to new demands, contribute to networking and agreements between health actions undertaken [15] [16]. Health attention network is understood as "the organizational arrangements of health actions and services, of different technological densities, that are integrated through technical support systems, logistics and management that lead to assurance of integrality of care" [17].

The presentation of this proposal of capacitation shows that from a targeted plan, a huge number of professionals can be reached, even in actions that incorporate practical training. As an indication of the potency of the experience, it was identified both by the professional tutors and the attendees that the multi professional training enriched them with a better comprehension of each specialty practice, as well as identified the items where health promotion guidelines can be fully performed by everyone, without distinction [18]. Thus, this program meets a current demand regarding care models, which should not be limited to individual and curative assistance, but should also contemplate programmatic actions that visualize groups, as well as educational actions in health. The advancement of health services organization in Brazil from the perspective of the construction of the SUS-Unified Health System-brings new challenges for the training of public health professionals who work in various health services, with the need to be continuous training for these teams, who often have high turnover within the public system.

Another fundamental question posed to the success of the experiment was the relocation of the tutor team to each administrative area, facilitating the participation of a higher number of professionals in each class, with a lower impact on the continuation of all services offered weekly. A greater participation of professionals from the Metropolitan region could be identified, which contains the largest portion of the population of the state, and in turn the largest number of health services, with expressive prominence of Professionals from Rio de Janeiro city, capital of the state. The registration data analysis also showed an adequate direction of the training actions in this city with a predominance of professionals from its most populous region, where $40.2 \%$ of the total population reside, and $22.88 \%$ of its residents have a per capita income below $1 / 2$ minimum wage [19].

The difference in weighting of professionals' participation in relation to their specialties reflects the distribution profile that they presented on the public network of child health assistance, until this moment a minimum level considered appropriate to the presented population demands was not observed, and was not also identified in totality, these factors constituting important research points to be answered.

It could be also identified that the strategy covered both the primary health attention team and the specialized rehabilitation team equally, composing one more important dialogue point to build an articulated and integrated assistance 
network. It's important to emphasize that the professionals who work on primary health attention mostly had a poor formal qualification for monitoring children with CZS, as reported by many of them throughout the performed activities, and many reported never having monitored a pediatric patient before, because they had other specialties in the health field. It is encouraging to note this level of involvement of the professionals during the discussions, especially because they are based on a critical analysis of the problems.

It is worthwhile to emphasize that all children with CZS and STORCH must have early stimulation, and it is not mandatory that this occur only in Rehabilitation Centre, because this care is fundamental to the development of many organic systems in the critical period to acquire motor, sensorial and adaptive behaviors [1] [10].

Thus, for integrated and articulated comprehensive health care actions, technical cooperation between different sectors should be increasingly encouraged so that guidelines can be established for good clinical practice at all levels. Overcoming the challenges and advancing the qualification of care requires strong decisions from SUS managers, as protagonists of the process of establishing and organizing the health system, as already pointed out by the Ministry of Health itself [17].

The virtual Knowledge portal, offered on more toll, enabled to provide higher level support so that the learning obtained during the course will be put into practice for the attendees

As potential inference of early stimulation activities with children with SCZ and STORCH, on the SES database (July 2019) may be observed a rising number of children on early stimulation monitoring increased from $20 \%$ of the total children monitoring in August 2018 to 36.9\% in July 2019 [11]. However, the low coverage of this kind of care on NASF services is due, predominantly, to the character of commission ascribed to NASFs in its implementation in Brazil. As the approach was centered on planning activities, health education and matrix support, the NASFs did not have in their agenda the prevision of individual direct assistance. Regarding the increase in number of early stimulation activities with children who have CZS and STORCH, we can see progress between pre and post activities performed, Therefore the NASF practices must go through a culture change, adapted to the new societal reality and for the questions that the CZS outbreak has raised for Brazil, where we find a higher necessity of family assistance provision close to affected families. It's also observed that all cities with NASFs received financial resources through the Ministry of Health from Ordinance number 3502, of 19 December 2017 to buy early stimulation kits, however, according to a survey conducted by SESRJ, none of the cities proceeded to buy these items. It's important to emphasize that the monitoring form used to accompany treatment of children with CZS and STORCH still have some usage failures, with under-registering of activities oriented to this public.

The potential of this program for socioeconomic impacts is large and diverse. 
In general, it is expected to achieve a higher degree of capacity for health education actions, since the repositioning of professionals in relation to families and their role in care can also contribute to the construction of more positive bonds between health workers and users; a better understanding of attitudes that, shared with the teams, allows a better quality of life as well as health promotion for children and their families/caregivers; early multidisciplinary care to these children, preventing morbidity associated with the lack of intervention; minimizing the family flow through multiple specialized health services, searching for rehabilitation care, that sometimes may prolong this search for months, which certainly optimizes the availability of vacancies in the public system of specialized attention [20].

\section{Final Considerations}

The proposal presented represents an integration of different strategic health sectors for the implementation of actions that specifically address integral care. The proposed action design appears to have allowed greater participation of health professionals working in primary care (NASFs and Primary Health Care) and specialized rehabilitation services in the State of Rio de Janeiro, and represents an important step towards the provision of a comprehensive care network for children with CZS. The action can also be transposed to other types of chronic health problems.

\section{Acknowledgements}

This study was supported by the Conselho Nacional de Desenvolvimento Científico e Tecnológico (CNPq) and Rio de Janeiro State Health Department.

\section{Conflicts of Interest}

The authors declare no conflicts of interest regarding the publication of this paper.

\section{References}

[1] Brasil (2018) Ministério da Saúde. Política Nacional de Atenção Integral à Saúde da Criança. Brasília.

[2] Brasil (2016) Ministério da Saúde. Secretaria de Atenção à Saúde. Diretrizes de estimulação precoce: crianças de zero a 3 anos com atraso no desenvolvimento neuropsicomotor. Ministério da Saúde, Brasília.

[3] Calheiros, M., Trevisan, C., Siebra, S. and Pinto, J. (2019) Atenção à criança: atenção integral às crianças com alterações do crescimento e desenvolvimento relacionadas às infecções Zika e Storch. Instituto Aggeu Magalhães, 150 p.

[4] Hazin, A.N., Poretti, A., Cruz, D.D.C.S., et al. (2016) Computed Tomographic Findings in Microcephaly Associated with Zika Virus. The New England Journal of Medicine, 374, 2193-2195. https://doi.org/10.1056/NEJMc1603617

[5] Moore, C.A., Staples, J.E., Dobyns, W.B., et al. (2017) Characterizing the Pattern of Anomalies in Congenital Zika Syndrome for Pediatric Clinicians. JAMA Pediatrics, 171, 288-295. https://doi.org/10.1001/jamapediatrics.2016.3982 
[6] Saad, T., Penna e Costa, A.A., de Góes, F.V., et al. (2018) Neurological Manifestations of Congenital Zika Virus Infection. Child s Nervous System, 34, 73-78. https://doi.org/10.1007/s00381-017-3634-4

[7] Silva, M.V.P., Pone, S.M., Zin, A.A., et al. (2018) Zika Virus Infection in Children: Epidemiology and Clinical Manifestations. Child s Nervous System, 34, 63-71. https://doi.org/10.1007/s00381-017-3635-3

[8] Brasil (2015) Ministério da Saúde. Portaria n 1.813, de 11 de novembro de 2015. Declara Emergência em Saúde Pública de importância Nacional (ESPIN) por alteração do padrão de ocorrência de microcefalias no Brasil. Ministério da Saúde.

[9] World Health Organization (2016) WHO Statement on the First Meeting of the International Health Regulations (2005) (IHR 2005) Emergency Committee on Zika virus and observed increase in neurological disorders and neonatal malformations.

[10] SAB/SAS/SRJ (2018) Plano de Execução da Estratégia de Fortalecimento das Ações de Cuidado das Crianças Suspeitas ou Confirmadas por SCZ e STORCH do Estado do Rio de Janeiro.

[11] Ayres, J.R.C.M. (2004) O cuidado, os modos de ser (do) humano e as práticas de saúde. Saúde e Sociedade, 13, 16-29.

https://doi.org/10.1590/S0104-12902004000300003

[12] Castro, M.C., et al. (2019) Brazil's Unified Health System: The First 30 Years and Prospects for the Future. The lancet, 394, 345-356.

https://doi.org/10.1016/S0140-6736(19)31243-7

[13] United Nation (2015) Transforming Our World: The 2030 Agenda for Sustainable Development. United Nations-Sustainable Development Knowledge Platform. https://nacoesunidas.org/wp-content/uploads/2015/10/agenda 2030-pt-br.pdf

[14] Brasil (2018) Ministério da Saúde. Secretaria de Atenção à Saúde. Departamento de Atenção Programáticas Estratégicas. Política Nacional de Atenção Integral à Saúde da Criança: Orientações para implementação/Ministério da Saúde. Secretaria de Atenção à Saúde. Departamento de Ações Programáticas Estratégicas. Ministério da Saúde, Brasília, 180 p.

[15] Ceccim, R.B. (2005) Educação permanente em saúde: Descentralização e disseminação de capacidade pedagógica na saúde. Ciência \& Saúde Coletiva, 10, 975-986. https://doi.org/10.1590/S1413-81232005000400020

[16] Mendes, E.V. (2009) Revisão bibliográfica sobre redes de atenção à saúde. Ministério da Saúde, Brasília.

[17] Brasil (2010) Ministério da Saúde. Portaria No. 4.279, De 30 De Dezembro De 2010 Estabelece diretrizes para a organização da Rede de Atenção à Saúde no âmbito do Sistema Único de Saúde (SUS).

[18] SA, M.R.C. and Gomes, R. (2013) A promoção da saúde da criança: a participação da Fisioterapia. Ciência \& Saúde Coletiva, 18, 1079-1088. https://doi.org/10.1590/S1413-81232013000400021

[19] Rio Como Vamos (2019) Monitorando a qualidade de vida na cidade. http://riocomovamos.org.br/indicadores-regionalizados/area/area-de-planejamento $-3 /$

[20] Ramos, J.F.C., Miranda, L., Peixoto, M.V.M., Marques, M.R., Mendes, L.C. and Pereira, E.H.P. (2018) Participative Research and Comprehensive Child Healthcare Promotion Strategies in the Brazilian National Health System (SUS). Interface, 22, 1077-1089. https://doi.org/10.1590/1807-57622017.0280 